Atmos. Chem. Phys., 13, 12059-12071, 2013

www.atmos-chem-phys.net/13/12059/2013/

doi:10.5194/acp-13-12059-2013

(c) Author(s) 2013. CC Attribution 3.0 License.

\title{
Climate and air quality trade-offs in altering ship fuel sulfur content
}

\author{
A. I. Partanen ${ }^{1}$, A. Laakso ${ }^{1}$, A. Schmidt ${ }^{2}$, H. Kokkola ${ }^{1}$, T. Kuokkanen ${ }^{3}$, J.-P. Pietikäinen ${ }^{4}$, V.-M. Kerminen ${ }^{5}$, K. E. \\ J. Lehtinen ${ }^{1,6}$, L. Laakso ${ }^{4,7}$, and H. Korhonen ${ }^{1}$ \\ ${ }^{1}$ Kuopio Unit, Finnish Meteorological Institute, Kuopio, Finland \\ ${ }^{2}$ School of Earth and Environment, University of Leeds, Leeds, UK \\ ${ }^{3}$ Department of Law, University of Eastern Finland, Joensuu Campus, Joensuu, Finland \\ ${ }^{4}$ Climate change, Finnish Meteorological Institute, Helsinki, Finland \\ ${ }^{5}$ Department of Physics, University of Helsinki, Helsinki, Finland \\ ${ }^{6}$ Department of Applied Physics, University of Eastern Finland, Kuopio campus, Kuopio, Finland \\ ${ }^{7}$ School of Physical and Chemical Sciences, North-West University, Potchefstroom Campus, Potchefstroom, South Africa
}

Correspondence to: A.-I. Partanen (antti-ilari.partanen@ @mi.fi)

Received: 20 June 2013 - Published in Atmos. Chem. Phys. Discuss.: 23 August 2013

Revised: 8 November 2013 - Accepted: 12 November 2013 - Published: 12 December 2013

\begin{abstract}
Aerosol particles from shipping emissions both cool the climate and cause adverse health effects. The cooling effect is, however, declining because of shipping emission controls aiming to improve air quality. We used an aerosol-climate model ECHAM-HAMMOZ to test whether by altering ship fuel sulfur content, the present-day aerosolinduced cooling effect from shipping could be preserved, while at the same time reducing premature mortality rates related to shipping emissions. We compared the climate and health effects of a present-day shipping emission scenario (ship fuel sulfur content of $2.7 \%$ ) with (1) a simulation with strict emission controls in the coastal waters (ship fuel sulfur content of $0.1 \%$ ) and twofold the present-day fuel sulfur content (i.e. 5.4\%) elsewhere; and (2) a scenario with global strict shipping emission controls (ship fuel sulfur content of $0.1 \%$ in coastal waters and $0.5 \%$ elsewhere) roughly corresponding to international agreements to be enforced by the year 2020. Scenario 1 had a slightly stronger aerosolinduced effective radiative forcing (ERF) from shipping than the present-day scenario $\left(-0.43 \mathrm{~W} \mathrm{~m}^{-2}\right.$ vs. $\left.-0.39 \mathrm{~W} \mathrm{~m}^{-2}\right)$ while reducing premature mortality from shipping by $69 \%$ (globally 34900 deaths avoided per year). Scenario 2 decreased the ERF to $-0.06 \mathrm{~W} \mathrm{~m}^{-2}$ and annual deaths by $96 \%$ (globally 48200 deaths avoided per year) compared to present-day. Our results show that the cooling effect of present-day emissions could be retained with simultaneous notable improvements in air quality, even though the shipping emissions from the open ocean clearly have a significant
\end{abstract}

effect on continental air quality. However, increasing ship fuel sulfur content in the open ocean would violate existing international treaties, could cause detrimental side-effects, and could be classified as geoengineering.

\section{Introduction}

Aerosol emissions from shipping have a net cooling effect on the Earth's climate, mainly through altering cloud properties, and cause detrimental health effects by degrading air quality (Eyring et al., 2010). Aerosol particles affect the climate in two ways. First, they scatter and absorb solar and terrestrial radiation (the aerosol direct effect, e.g. Myhre et al., 2013). Second, changes in the aerosol loading induce changes in cloud microphysical properties and cloud lifetime (the aerosol indirect and semidirect effects, e.g. Koch and Del Genio, 2010; Lohmann and Feichter, 2005). One well-known example of the aerosol indirect effects are the so-called ship tracks that sometimes manifest along the shipping routes (Christensen and Stephens, 2011; Coakley et al., 1987). They are clouds with enhanced reflectivity due to increased droplet number concentration (accompanied by decreased droplet size) caused by aerosol emissions from shipping. Eyring et al. (2010) reported a range between $-0.038 \mathrm{~W} \mathrm{~m}^{-2}$ and $-0.6 \mathrm{~W} \mathrm{~m}^{-2}$ for the aerosol indirect effects from shipping for the year 2000 from several independent modelling studies. 
In terms of health effects, aerosol particles increase premature mortality due to lung cancer and cardiopulmonary diseases (Pope and Dockery, 2006). Globally, air pollution is estimated to cause about 0.8 million premature deaths per year (Cohen et al., 2005). Particulate emissions from international shipping have been considered responsible for 18900 90600 deaths per year (Corbett et al., 2007; Winebrake et al., 2009).

As the knowledge of the adverse health and environmental effects of shipping emissions has increased, governments have negotiated treaties to reduce air pollution, especially sulfur emissions from ship traffic. The International Maritime Organization (IMO) has been responsible for the detailed regulation of pollution from ships. The leading IMO agreement on the pollution from ships is the MARPOL 73/78 Convention (IMO, 1978). In 1997, Annex VI was added to the convention to minimize airborne emissions from ships. In 2008, emissions limits of the annex, including sulfur oxides in Regulation 14, were further tightened (IMO, 2008). According to the amendment, a global cap of $3.5 \%$ has been applied for ship fuel sulfur content from 1 January 2012 onwards. In certain emission control areas, such as in the North Sea, Baltic Sea and the coastal areas of the USA and Canada, a stricter restriction of $0.1 \%$ will be in effect by 2015 . The global sulfur cap will be progressively reduced to $0.5 \%$ by the year 2020, although the IMO is required to complete a review by 2018 of the availability of fuel with sulfur content no greater than $0.5 \%$.

The health benefits of shipping emission cuts have been estimated by model studies. Winebrake et al. (2009) calculated that setting a ship fuel sulfur limit of $0.1 \%$ in the coastal regions within 200 nautical miles $(370 \mathrm{~km})$ from the coastlines could save 15 400-73 500 lives annually. However, there are trade-offs involved in decreasing sulfur and organic carbon emissions from shipping by reducing sulfur content in the ship fuel. The net cooling effect from ship-emitted aerosols will decrease simultaneously with the adverse health effects. Lauer et al. (2009) estimated that applying a ship fuel sulfur content limit of $0.5 \%$ globally would decrease the radiative forcing of shipping emissions from $-0.6 \mathrm{~W} \mathrm{~m}^{-2}$ to $-0.3 \mathrm{~W} \mathrm{~m}^{-2}$ and hence accelerate global warming.

Fuglestvedt et al. (2009) discussed the idea of refraining from shipping emission reductions to cool the climate, and rejected it based on the many uncertainties and risks involved. However, several technologies using controlled aerosol emissions to cool the climate have been proposed in recent years (e.g. marine cloud whitening, Latham, 1990, and stratospheric sulfur injections, Crutzen, 2006). In a broader context, these technologies are known as solar radiation management (SRM) or geoengineering (Fox and Chapman, 2011). Despite the uncertainties and risks involved (Robock, 2008) it may be worth studying these technologies as they may be considered in the future if greenhouse gas emission reductions are not successful or climate sensitivity is underestimated.
The aim of our study is to test whether the presentday radiative aerosol-induced cooling (excluding greenhouse gases) from shipping could be preserved while at the same time reducing the mortality related to shipping emissions. Using a global model, we explore a scenario in which the ship fuel sulfur content is increased in the open oceans (entire sea area excluding coastal zones) but reduced in the coastal zones. This scenario can be considered a form of geoengineering because of the deliberate attempt to assert a cooling effect on the climate. The geoengineering scenario is compared to shipping emission scenarios for the years 2010 and 2020. To make the climate and air quality trade-offs evident, different scenarios are compared with respect to the global mean effective radiative forcing (ERF) resulting from aerosol effects and global premature mortality due to shipping emissions. We do not attempt to compare these metrics with each other (i.e. try to evaluate how many deaths caused by climate change could be avoided with a certain amount of ERF), because that would require several arbitrary simplifications (Löndahl et al., 2010), and would be outside the scope of this paper. Our study is not intended as a policy recommendation, but it provides valuable information about the climate and air quality trade-offs related to aerosol emissions from international shipping.

\section{Methods}

\subsection{Model description}

We used the global aerosol-climate model ECHAMHAMMOZ (ECHAM5.5-HAM2.0) (Stier et al., 2005; Zhang et al., 2012) to quantify the effects of shipping emissions on climate and air quality. The model uses the M7 aerosol microphysics scheme (Vignati et al., 2004) to describe the externally and internally mixed aerosol population and its size distribution with seven log-normal modes containing the aerosol species of sulfate $\left(\mathrm{SO}_{4}\right)$, sea salt, organic carbon, black carbon and mineral dust. The aerosol model resolves nucleation of new particles from sulfuric acid (Kazil and Lovejoy, 2007), condensation of sulfuric acid vapor, coagulation, hydration and removal of aerosol particles by dry deposition, sedimentation and wet deposition. We used AEROCOMII ACCMIP data for anthropogenic aerosol emissions and biomass burning emissions for the year 2010 (Riahi et al., 2007,2011 ) and natural aerosol emissions as described by Zhang et al. (2012). The model simulates the aerosol-cloud interactions, including both first and second aerosol indirect effects as described by Lohmann and Hoose (2009). The cloud droplet activation was calculated with a physically based parameterization (Abdul-Razzak and Ghan, 2000). We implemented the model modifications done by Peters et al. (2012) to set all shipping emissions consistently in the first model layer, assigning primary sulfate, organic carbon and black carbon emissions from shipping to the soluble Aitken 
mode with a geometric mean radius of $44 \mathrm{~nm}$ for sulfate and $30 \mathrm{~nm}$ for carbonaceous species. The chosen mode diameters are smaller than the default sizes in ECHAM-HAM (Stier et al., 2005; Zhang et al., 2012) reflecting recent measurements of ship emissions (e.g., Petzold et al., 2008; Jonsson et al., 2011). Our choice of diameter for carbonaceous aerosols is close to the value reported by Petzold et al. (2008), who measured the number density of the non-volatile combustion mode to be dominated by particles with radius of $40 \mathrm{~nm}$. However, the diameter for primary sulfate emissions in our study is somewhat larger than found in the Petzold et al. (2008) study. Since smaller particles mean more cloud condensation nuclei (provided that the particles are still large enough to activate as cloud droplets), the sulfate diameter used in our model version can potentially lead to an underestimation of the aerosol indirect effect (Peters et al., 2013). However, different measurements campaigns have yielded highly varying results for the primary sulfate particle size (Petzold et al., 2008; Jonsson et al., 2011) reflecting the fact that it is difficult to extract the diameter of particles from shipping emissions based on measurements due to, e.g. several chemical components involved, plume aging, and variability of engines.

\subsection{Experiment design}

Our simulations differed from each other only with respect to shipping emissions. A list of all simulations is provided in Table 1. The reference simulation called no-ships was run without any shipping emissions at all. To assess the effects of present-day aerosol emissions from shipping, we used the shipping emissions from ACCMIP database (Riahi et al., 2007, 2011) for the year 2010 (Fig. 1a) in the simulation ships-2010.

For the rest of the simulations, we defined the coastal zones within one or two (depending on the simulation) model grid cells away from the continent as emission control areas where fuel sulfur content was assumed to be $0.1 \%$, corresponding to the limit in existing emission reduction areas from the year 2015. The width of the emission reduction zones corresponds roughly to the 200 nautical miles $(370 \mathrm{~km})$ equivalent to the width of the current emission control area surrounding North America (IMO, 2010). In the geoengineering simulations geo-wide and geo-narrow we set the fuel sulfur content to $5.4 \%$ (double the current global mean value) outside the coastal waters (i.e., in the area at least two grid cells $(400-600 \mathrm{~km})$ or one grid cell $(200-300 \mathrm{~km})$ away from the coastline, respectively).

To compare the geoengineering simulations against a strict emission control scenario, we set up a simulation ships-2020 that roughly corresponds to the shipping emission regulation planned for the year 2020. In ships-2020, we assumed that the coastal zones, within 2 grid cells from the continent, correspond to the emission control areas with a limit of $0.1 \%$ on the ship fuel sulfur content, and applied the global cap of
$0.5 \%$ elsewhere. The assumption that emission control areas cover all the coastal waters is overestimating the extent of the emission reduction areas, but it gives an idea of the effects of the planned future emission control legislation. We did not take into account any possible changes in the shipping routes or shipping activity in the future because we wanted to compare different idealized emission control scenarios, and not make future projections.

To calculate the actual sulfur dioxide $\left(\mathrm{SO}_{2}\right)$ emissions in different scenarios, the ACCMIP shipping emissions for the year 2010 were used as a baseline. We assumed that the fuel sulfur content in each grid cell of the ACCMIP emissions was equal to the current global mean value of $2.7 \%$ (Lauer et al., 2009) and that $\mathrm{SO}_{2}$ emissions were linearly dependent on the fuel sulfur content. Thus, in emission control areas with a sulfur content limit of $0.1 \%$, the baseline shipping emissions were multiplied by $0.037(=0.1 \% / 2.7 \%)$ and doubled in the geoengineered regions to a ship fuel sulfur content of $5.4 \%$. Organic carbon emissions were scaled similarly using the relationship reported by Lack et al. (2009) for fuel sulfur content (S\%) and organic carbon emissions (OC) (OC $\left.\left(\mathrm{g} \mathrm{kg}^{-1}\right)=0.65 \times \mathrm{S} \%+0.5\right)$. There is no such simple dependence of black carbon emissions on fuel sulfur content as one major determining factor is engine load, although fuel quality also plays a role (Lack and Corbett, 2012). Lacking a precise formulation, we used the unmodified black carbon emissions from the ACCMIP database for all simulations. Not accounting for any changes in black carbon emissions is unlikely to affect our results significantly. First, Peters et al. (2012) showed that omitting black carbon emissions from shipping had little effect on the net aerosol radiative forcing from shipping as increased nucleation of new particles compensated for the missing black carbon. Second, emitted black carbon mass from shipping is low compared to sulfur dioxide mass (Table 1), and changes in aerosol mass (instead of in composition) determines the calculated health effects in our study (see Sect. 2.3).

The fraction of sulfur emissions that should be treated as primary sulfate due to subgrid scale nucleation in models is uncertain (Luo and Yu, 2011; Stevens et al., 2012) and affects the impacts of shipping emissions as the burden of sulfate increases with increasing primary sulfate fraction (Peters et al., 2012). To test the sensitivity of our results to this factor, we did sensitivity simulations ships-2010_45 and geo-wide_45 in which $4.5 \%$ (instead of $2.5 \%$ ) of sulfur mass emissions from ships was emitted as primary sulfate. In all other respects, the simulations were identical to ships-2010 and geowide, respectively. For other anthropogenic sources besides shipping, a fraction of $2.5 \%$ (Dentener et al., 2006; Zhang et al., 2012) was used in all the simulations.

Different shipping emission inventories differ greatly from each other with respect to both the spatial distribution and the global sum of the emissions (Eyring et al., 2010). To assess the sensitivity of our results to the spatial distribution of the shipping emissions, we carried out two additional sensitivity 
Table 1. List of simulations*.

\begin{tabular}{lrrrrrrr}
\hline Simulation & $\begin{array}{r}\mathrm{S} \% \\
\text { coast }\end{array}$ & $\begin{array}{r}\mathrm{S} \% \\
\text { ocean }\end{array}$ & $\begin{array}{r}\text { Coast } \\
\text { width }\end{array}$ & $\begin{array}{r}\mathrm{SO}_{2} \\
\left(\mathrm{Tgyr}^{-1}\right)\end{array}$ & $\begin{array}{r}\mathrm{OC} \\
\left(\mathrm{Tgyr}^{-1}\right)\end{array}$ & $\begin{array}{r}\mathrm{BC}^{-1} \\
\left(\mathrm{Tgyr}^{-1}\right)\end{array}$ & $f_{\mathrm{SO}_{4}}$ \\
\hline Main simulations & - & - & - & - & - & - & - \\
no-ships & - & - & - & 0 & 0 & 0 & - \\
ships-2010 & $2.7 \%$ & $2.7 \%$ & - & 12.50 & 0.16 & 0.15 & $2.5 \%$ \\
geo-narrow & $0.1 \%$ & $5.4 \%$ & 1 & 17.37 & 0.21 & 0.15 & $2.5 \%$ \\
geo-wide & $0.1 \%$ & $5.4 \%$ & 2 & 13.12 & 0.17 & 0.15 & $2.5 \%$ \\
ships-2020 & $0.1 \%$ & $0.5 \%$ & 2 & 1.42 & 0.05 & 0.15 & $2.5 \%$ \\
Sensitivity simulations & & & & & & & \\
ships-2010_45 & $2.7 \%$ & $2.7 \%$ & - & 12.50 & 0.16 & 0.15 & $4.5 \%$ \\
geo-wide_45 & $0.1 \%$ & $5.4 \%$ & 2 & 13.12 & 0.17 & 0.15 & $4.5 \%$ \\
ships-2010_corbett & $2.7 \%$ & $2.7 \%$ & - & 12.52 & 0.16 & 0.15 & $2.5 \%$ \\
geo-wide_corbett & $0.1 \%$ & $5.4 \%$ & 2 & 11.81 & 0.15 & 0.15 & $2.5 \%$
\end{tabular}

* The second and third columns give the ship fuel sulfur content (S \%) for coastal zones and open ocean, respectively. Sulfur content is used to scale $\mathrm{SO}_{2}$ and $\mathrm{OC}$ emissions. Coast width is the number of grid cells from the coastline that determine the coastal zone for emission reductions. The next three columns give the total global annual emissions of sulfur dioxide $\left(\mathrm{SO}_{2}\right.$, including the fraction emitted as primary sulfate), organic carbon (OC) and black carbon (BC) from shipping. The last column gives the fraction of sulfur mass emissions from shipping which is actually emitted as primary sulfate particles in the model to emulate subgrid scale sulfate formation.

a)

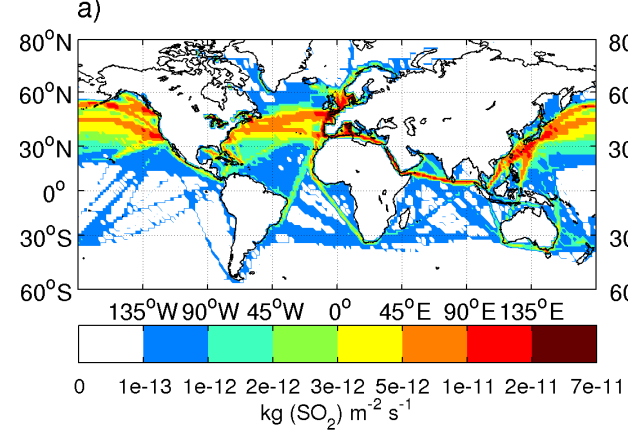

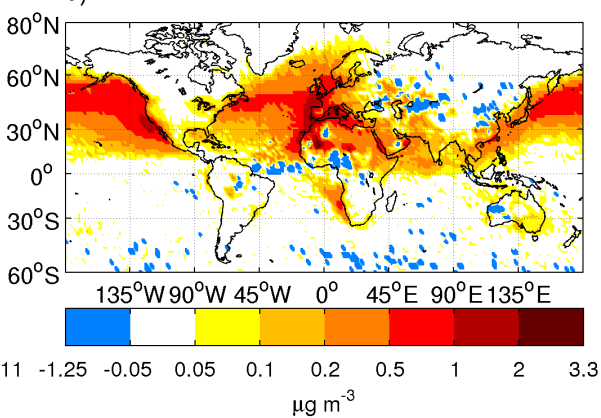

Fig. 1. (a) $\mathrm{SO}_{2}$ emissions from ship traffic in the simulation ships-2010. The emissions are from the ACCMIP database for the year 2010 . (b) The contribution of shipping emissions to $\mathrm{PM}_{2.5}$ mass concentrations in the simulation ships-2010.

simulations that used the combined shipping emission data compiled by Corbett et al. (2010) for the Arctic and by Wang et al. (2008) for the rest of the world. Simulation ships-2010_corbett used these combined emissions for the year 2010. As the global sum of the shipping emissions by Wang et al. (2008) was also taken from the RCP8.5 scenario (Riahi et al., 2007, 2011), the total global shipping emissions were almost the same in both ships-2010 and ships2010_corbett (Table 1). Shipping emissions for the simulation geo-wide_corbett were calculated in the same way as for geo-wide, but emissions from Wang et al. (2008) and Corbett et al. (2010) were used as the baseline instead of the ACCMIP emissions.

Due to the model version used, our analysis includes only sulfur, organic carbon, and black carbon aerosol emissions from shipping. Other main aerosol and aerosol precursor compounds in shipping emissions include nitrogen oxides and volatile organic compounds (Eyring et al., 2010). Lieke et al. (2013) measured also crystalline salts in the ship ex- hausts. Not including these other compounds may lead to an underestimation of aerosol-related climate and health effects of shipping.

All the simulations were run in the horizontal resolution of T63 corresponding roughly to a $1.9^{\circ} \times 1.9^{\circ}$ grid. The model had 31 vertical levels and extended to a pressure level of $10 \mathrm{hPa}$. The simulation time was five model years from 2001 to 2005 for each simulation. The model meteorology (vorticity, divergence, temperature and surface pressure) was nudged towards the reference state by ERA-interim reanalysis data (Dee et al., 2011). The runs were preceded by a threemonth spinup period of which the first two months were common in all simulations and had no shipping emissions. The model was run with climatological sea surface temperatures. 


\subsection{Calculation of premature mortality due to shipping emissions}

The model diagnosed the mass concentrations of particulate matter with dry diameters less than $2.5 \mu \mathrm{m}\left(\mathrm{PM}_{2.5}\right)$ by integrating the contribution of each of the seven modes separately. We used five-year-mean values of surface level $\mathrm{PM}_{2.5}$ concentration to estimate the long-term health effects for each shipping emission scenario. The simulation no-ships was used as the reference. We followed the recommendations by Ostro (2004) to calculate the premature mortality from lung cancer (Trachea, bronchus and lung cancers) and cardiopulmonary diseases (cardiovascular diseases and chronic obstructive pulmonary disease) due to long-term exposure to shipping emissions. The concentration-response function that relates changes in $\mathrm{PM}_{2.5}$ concentrations to annual excess mortality rates ( $E$, deaths per year) can be expressed as

$E=\left[1-\left(\frac{\mathrm{PM}_{2.5,0}+1}{\mathrm{PM}_{2.5,1}+1}\right)^{\beta}\right] \times B_{\mathrm{y}} \times P_{30+}$,

where $\mathrm{PM}_{2.5,0}$ is the reference concentration $\left(\mu \mathrm{g} \mathrm{m}^{-3}\right)$ in noships and $\mathrm{PM}_{2.5,1}$ the concentration in the simulation under investigation; $\beta$ is a cause-specific coefficient with a value of 0.23218 (95\% confidence interval: $0.08563-0.37873$ ) for lung cancer and 0.15515 (95\% confidence interval: 0.05620.2541 ) for cardiopulmonary diseases (Ostro, 2004); $B_{\mathrm{y}}$ is the baseline mortality rate (e.g., deaths per year per 1000 people) for lung cancer or cardiopulmonary diseases in the exposed population with age over $30 \mathrm{yr}\left(P_{30+}\right)$.

Baseline mortality rates and the fraction of people in the exposed age-group were calculated using data provided by the World Health Organisation (WHO, 2008) based on six WHO regions (Fig. 2) gridded onto the model grid resolution. We used the population density data for the year 2010 from the Sosioeconomic Data and Applications Center at Columbia University (SEDAC, 2005). Population density was also interpolated onto the model grid resolution.

\section{Results}

\subsection{Effects of shipping emissions on $\mathbf{P M}_{2.5}$ concentrations}

We estimated the contribution of shipping emissions to $\mathrm{PM}_{2.5}$ by calculating the difference between the $\mathrm{PM}_{2.5}$ values of the simulation no-ships and those of the other simulations. The comparison of the modelled $\mathrm{PM}_{2.5}$ concentrations against measurements is discussed in Sect. 3.4.1.

Contribution of shipping emissions to $\mathrm{PM}_{2.5}$ in the simulation ships-2010 is shown in Fig. 1b. The effect of ship traffic was most prominent in the coastal areas of western Europe, where $\mathrm{PM}_{2.5}$ is about $0.5-2 \mu \mathrm{g} \mathrm{m}^{-3}$ higher due to shipping emissions. In the coastal regions of Europe this corresponds to a relative increase of up to about $20 \%$ due to

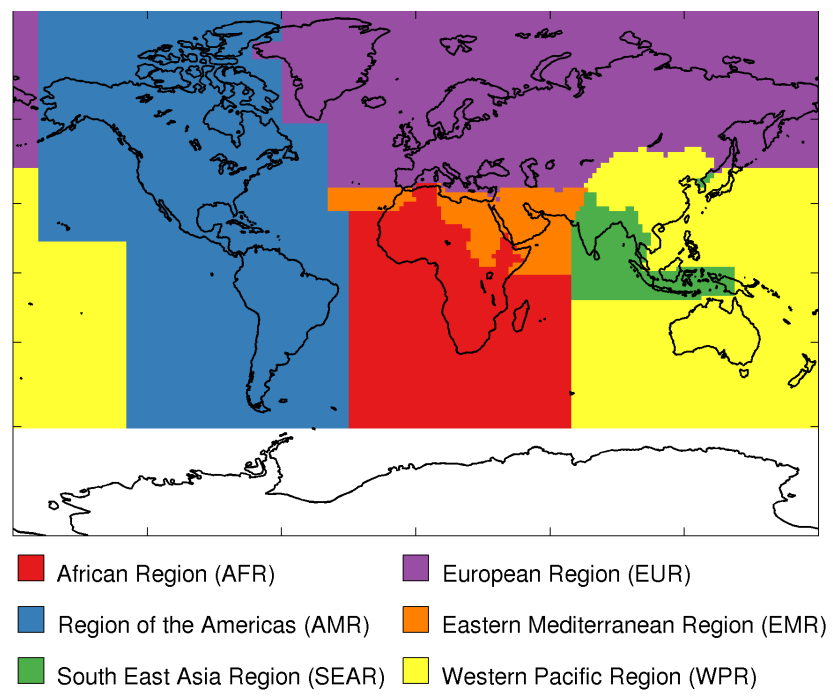

Fig. 2. Definition of the WHO regions based on a list of countries in each region (WHO, 2012) and gridded data set of the world's countries (Lerner et al., 1988).

the major shipping routes passing through the English Channel and Mediterranean Sea (Fig. 1a). Corbett et al. (2007) and Winebrake et al. (2009) estimated a contribution of ship traffic to $\mathrm{PM}_{2.5}$ of up to about $2 \mu \mathrm{g} \mathrm{m}^{-3}$ and about $3 \mu \mathrm{g} \mathrm{m}{ }^{-3}$, respectively. These numbers agree quite well with the maximum $\mathrm{PM}_{2.5}$ contribution of $3.3 \mu \mathrm{g} \mathrm{m}^{-3}$ from shipping in our simulation ships-2010.

Continental air quality was notably improved in the simulations with emission reductions near the coasts. For example, in the geoengineering simulation with the wide emission reduction zone (geo-wide), the contribution of shipping emissions to $\mathrm{PM}_{2.5}$ concentration was less than $0.5 \mu \mathrm{g} \mathrm{m}{ }^{-3}$ almost everywhere in Europe. That is a reduction of roughly between $-1 \%$ and $-15 \%$ in total $\mathrm{PM}_{2.5}$ mass concentration in Europe compared to the simulation ships-2010. In the simulation corresponding to future emission controls ships2020), the contribution of shipping emissions to $\mathrm{PM}_{2.5}$ was less than $0.1 \mu \mathrm{g} \mathrm{m}^{-3}$ almost everywhere in Europe. The effect of shipping emissions in ships-2020 on $\mathrm{PM}_{2.5}$ was so low that the natural variability of aerosol concentrations is greater than the contribution of shipping emissions to $\mathrm{PM}_{2.5}$ in most parts of the world. The difference in continental $\mathrm{PM}_{2.5}$ concentration between geo-wide and ships-2020, which have the same coastal emissions, shows that emissions from the open ocean contributed significantly to continental $\mathrm{PM}_{2.5}$ concentration in geo-wide.

\subsection{Premature mortality due to shipping emissions}

We calculated premature mortality from lung cancer and cardiopulmonary diseases due to long-term exposure to shipping emissions using the $\mathrm{PM}_{2.5}$ concentration in the simulation no-ships as the reference concentration. Of the studied 
main cases (i.e. excluding sensitivity simulations which are discussed in Sect. 3.4), current shipping emissions caused the most deaths (50 200 deaths per year in ships-2010, Table 2). Both geoengineering scenarios resulted in significant drops in mortality rates due to ship- $\mathrm{PM}_{2.5}$ compared to the simulation ships-2010. The global excess mortality due to shipping decreased by $15400(31 \%)$ and by $34900(69 \%)$ in the simulations geo-narrow and geo-wide, respectively. The large difference between the geoengineering scenarios shows that the width of the emission reduction zone had a significant impact. As expected, the simulation ships-2020 offered the most health benefits, reducing ship- $\mathrm{PM}_{2.5}$-induced mortality by 48200 (96\%) compared to ships-2010. The relative decrease of ship- $\mathrm{PM}_{2.5}$-induced mortality was much higher than estimates by Winebrake et al. (2009) for different emission control scenarios. They calculated that a cap of $0.1 \%$ for ship fuel sulfur content in the coastal areas would decrease the mortality from shipping emissions by about $50 \%$ and a global cap of $0.5 \%$ by about $40 \%$ or $50 \%$ depending on the emission inventory used. Simulations by Winebrake et al. (2009) are not directly comparable to our simulation ships-2020, because ships-2020 had both coastal and global caps for fuel sulfur content in use.

Figure 3 shows the excess mortality due to ship- $\mathrm{PM}_{2.5}$ for ships-2010, geo-wide and ships-2020. As expected from the results on $\mathrm{PM}_{2.5}$ concentration (Fig. 1b), Europe was estimated to suffer most from current shipping emissions and could greatly benefit from emission reductions. We estimated the total excess mortality from shipping emissions in the $\mathrm{Eu}-$ ropean Region (includes Northern Asia in the WHO definition, see Fig. 2) to be about 27300,7500 and 1300 in ships2010, geo-wide and ships-2020, respectively (Table 3). Summing the total mortality rates for South East Asia Region and Western Pacific Region (as defined by WHO (2012), see Fig. 2), the respective figures are only about 13100,4800 and 100 , although the total exposed population (age $>30 \mathrm{yr}$ ) is 1.7 billion in those regions compared to 0.5 billion in the European Region. The area displayed in Fig. 3 (between latitudes of $15^{\circ} \mathrm{S}$ and $65^{\circ} \mathrm{N}$ ) encompasses $98 \%$ of the global excess mortality due to shipping emissions in ships-2010. Therefore, countries in the Southern Hemisphere suffered relatively little from shipping emissions and use of low-sulfur fuel would thus bring few health benefits there.

The simulation ships-2020 predicted at least $91 \%$ decrease in total mortality resulting from shipping for all the WHO regions (compared to ships-2010). Of the two main geoengineering runs, geo-wide decreased regional mortality rates caused by shipping by between $55 \%$ and $81 \%$. In general, the relative decrease of regional excess mortality was very similar in each region for a given simulation. The main exception was the simulation geo-narrow. For example, the total mortality from shipping emissions in geo-narrow in the eastern Mediterranean Region dropped by $58 \%$ (about 1600 less than in ships-2010), but increased by $1 \%$ (about 100 deaths more than in ships-2010) in the Western Pacific Re- a)

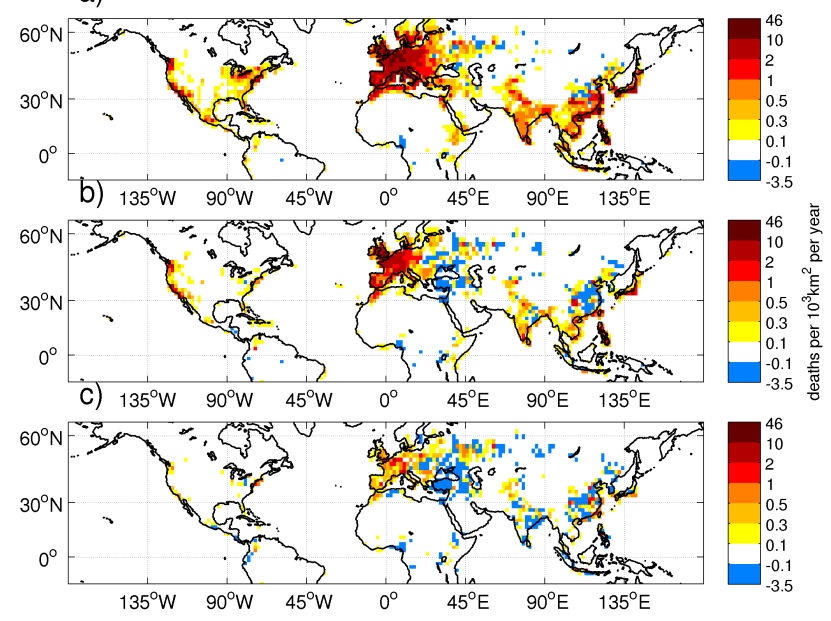

Fig. 3. Sum of excess annual mortality from cardiopulmonary diseases and lung cancer due to shipping emissions in simulations (a) ships-2010, (b) geo-wide and (c) ships-2020.

gion. This was most likely caused by the fact that shipping routes in the Mediterranean Sea and North Sea are located very close the coasts, but the shipping routes near China are further away from the continent (Fig. 1a) and beyond the onegrid-cell emission reduction zone.

\subsection{Comparison of the radiative effects}

We estimated the radiative effect of shipping emissions as effective radiative forcing (ERF, also known as radiative flux perturbation, RFP) (Haywood et al., 2009) (i.e. the difference of all-sky top-of-the-atmosphere net (down minus up) total (short- and longwave) radiation between two simulations with fixed sea surface temperatures). ERF includes both aerosol direct and indirect effects, and makes it possible to compare total aerosol forcing with forcing from well-mixed greenhouse gases (Lohmann et al., 2010). In the simulation ships-2010, the global mean ERF (compared to no-ships) was $-0.39 \mathrm{~W} \mathrm{~m}^{-2}$ (Table 2). This is close to the mean value of $-0.44 \mathrm{~W} \mathrm{~m}^{-2}$ for the shipping-induced aerosol forcing (for the year 2005) estimated by Eyring et al. (2010) by combining several independent modelling studies. Peters et al. (2012) estimated a similar ERF of $-0.36 \mathrm{~W} \mathrm{~m}^{-2}$ for the total aerosol radiative effect with the same model, a similar treatment of shipping emissions, and similar amount of $\mathrm{SO}_{2}$ emissions $\left(12.95 \mathrm{Tg}\left(\mathrm{SO}_{2}\right) \mathrm{yr}^{-1} \mathrm{com}-\right.$ pared to $12.50 \mathrm{Tg}\left(\mathrm{SO}_{2}\right) \mathrm{yr}^{-1}$ in our simulation) as used in our study. There are two major differences between our study and the simulations by Peters et al. (2012). First, they used an empirical parameterization (Lin and Leaitch, 1997) for cloud droplet activation as opposed to the physically based parameterization (Abdul-Razzak and Ghan, 2000) in our study. Second, Peters et al. (2012) assumed that $4.5 \%$ of the sulfur mass emissions from shipping are emitted as primary $\mathrm{SO}_{4}$ 
Table 2. Global mean effective radiative forcing (ERF) $\left(\mathrm{W} \mathrm{m}^{-2}\right)$ and global excess mortality due to shipping emissions (deaths per year)*

\begin{tabular}{lrrr}
\hline Simulation & ERF & Lung cancer & Cardiopulmonary diseases \\
\hline ships-2010 & $-0.39 \pm 0.03$ & $5100(1900-8300)$ & $45100(16400-73700)$ \\
geo-narrow & $-0.53 \pm 0.02$ & $3600(1300-5900)$ & $31200(11300-51100)$ \\
geo-wide & $-0.43 \pm 0.02$ & $1600(600-2600)$ & $13800(5000-22600)$ \\
ships-2020 & $-0.06 \pm 0.02$ & $200(100-400)$ & $1800(600-2900)$ \\
ships-2010_45 & $-0.50 \pm 0.02$ & $5500(2000-9000)$ & $48800(17700-79700)$ \\
geo-wide_45 & $-0.54 \pm 0.02$ & $2100(800-3400)$ & $17900(6500-29300)$ \\
ships-2010_corbett & $-0.37 \pm 0.01$ & $4800(1800-7800)$ & $42500(15400-69500)$ \\
geo-wide_corbett & $-0.40 \pm 0.01$ & $1800(700-3000)$ & $16400(6000-26900)$ \\
\hline
\end{tabular}

* The uncertainty of global mean ERF is given as a standard deviation of annual global mean of ERF. The first number for mortality rates is the best estimate for the mortality, and the numbers in the parentheses represent the uncertainty range ( $95 \%$ confidence interval) from the concentration-response function coefficients. The mortality values are rounded to the nearest 100 .

Table 3. Regional annual premature mortality due to shipping emissions in different scenarios (deaths per year)*

\begin{tabular}{|c|c|c|c|c|c|c|}
\hline Simulation & AFR & AMR & SEAR & EUR & EMR & WPR \\
\hline \multicolumn{7}{|c|}{ Lung cancer } \\
\hline ships-2010 & $20(10-30)$ & $880(330-1430)$ & $170(60-270)$ & $2850(1060-4630)$ & $80(30-120)$ & $1140(420-1850)$ \\
\hline geo-narrow & $20(10-30)$ & $680(250-1100)$ & $140(50-230)$ & $1630(600-2650)$ & $30(10-50)$ & $1150(420-1870)$ \\
\hline geo-wide & $10(0-10)$ & $320(120-520)$ & $80(30-120)$ & $790(290-1280)$ & $10(10-20)$ & $370(140-2570)$ \\
\hline ships-2020 & $0(0-0)$ & $80(30-130)$ & $-10(0-10)$ & $140(50-220)$ & $0(0-0)$ & $30(10-400)$ \\
\hline ships-2010_45 & $30(10-40)$ & $960(360-1560)$ & $180(70-290)$ & $3160(1170-5130)$ & $80(30-130)$ & $1120(410-8980)$ \\
\hline geo-wide_45 & $10(0-20)$ & $410(150-670)$ & $80(30-140)$ & $970(360-1580)$ & $20(10-40)$ & $570(210-3360)$ \\
\hline ships-2010_corbett & $30(10-40)$ & $1060(390-1730)$ & $200(80-330)$ & $2320(860-3760)$ & $80(30-120)$ & $1100(410-7790)$ \\
\hline geo-wide_corbett & $10(0-20)$ & $350(130-570)$ & $110(40-180)$ & $810(300-1330)$ & $20(10-30)$ & $510(190-2960)$ \\
\hline \multicolumn{7}{|c|}{ Cardiopulmonary diseases } \\
\hline ships-2010 & $1150(420-1880)$ & $5150(1870-8420)$ & $3890(1410-6370)$ & $24420(8880-39860)$ & $2620(950-4280)$ & $7870(2850-12880)$ \\
\hline geo-narrow & $950(340-1560)$ & $3970(1440-6500)$ & $3310(1200-5420)$ & $13940(5060-22780)$ & $1110(400-1810)$ & $7950(2880-13010)$ \\
\hline geo-wide & $340(120-550)$ & $1890(680-3090)$ & $1760(640-2890)$ & $6720(2440-11000)$ & $500(180-820)$ & $2580(930-4220)$ \\
\hline ships-2020 & $-60(-20-100)$ & $470(170-770)$ & $-130(-50-210)$ & $1180(430-1920)$ & $80(30-120)$ & $230(80-370)$ \\
\hline ships-2010_45 & $1410(510-2300)$ & $5640(2050-9220)$ & $4110(1490-6730)$ & $27060(9840-44$ 150) & $2810(1020-4590)$ & $7760(2810-12690)$ \\
\hline geo-wide_45 & $550(200-890)$ & $2410(870-3940)$ & $1960(710-3200)$ & $8310(3010-13590)$ & $750(270-1230)$ & $3920(1420-6420)$ \\
\hline ships-2010_corbett & $1440(520-2360)$ & $6240(2260-10200)$ & $4740(1720-7770)$ & $19820(7200-32380)$ & $2620(950-4280)$ & $7630(2760-12480)$ \\
\hline geo-wide_corbett & $720(260-1180)$ & $2060(750-3370)$ & $2520(910-4120)$ & $6960(2520-11390)$ & $650(240-1070)$ & $3510(1270-5750)$ \\
\hline
\end{tabular}

particles, compared to $2.5 \%$ used in our ships-2010 simulation. The sensitivity of our results to this parameter is discussed in Sect. 3.4.2.

The ERF in ships-2010 had a strong spatial variation (Fig. 4a). The effect of shipping emissions was largely confined to the Northern Hemisphere. The strongest cooling effect was in the stratocumulus region of the North Pacific where the regional ERF attained values in the order of $-10 \mathrm{~W} \mathrm{~m}^{-2}$. In this region, there are both frequent low-level clouds that are susceptible to additional aerosol emissions (e.g. Partanen et al., 2012) and high shipping emissions from major trade routes (Fig. 1a).

In the simulation geo-wide, the largest (most negative) ERF was in the open sea due to emission reductions near the coasts (Fig. 4b). The ERF in the stratocumulus region of South Atlantic was diminished compared to ships-2010 as the cloud region and the nearby major shipping route (Fig. 1a) lie partly in the emission reduction zone. In North
Pacific, the stratocumulus region and shipping routes extend further away to the sea and the total radiative effect was stronger in the geoengineering simulations than in ships2010. Despite the large emission reduction near the continents, the global mean ERFs in the geoengineering simulations $\left(-0.43 \mathrm{~W} \mathrm{~m}^{-2}\right.$ in geo-wide and $-0.53 \mathrm{~W} \mathrm{~m}^{-2}$ in geonarrow) were stronger compared to that in ships-2010. In the simulation ships-2020, the radiative effect of shipping emissions almost disappears (Fig. 4c) as the global mean ERF is only $-0.06 \mathrm{~W} \mathrm{~m}^{-2}$. The absolute difference in ERFs between ships-2020 and ships-2010 was very similar to the estimates by Lauer et al. (2009) for a scenario with a global fuel sulfur content cap of $0.5 \%$ and a non-controlled emission scenario for the year 2012. However, the relative difference in the radiative effects between their scenarios was only $53 \%$ whereas in our case it was $85 \%$. 


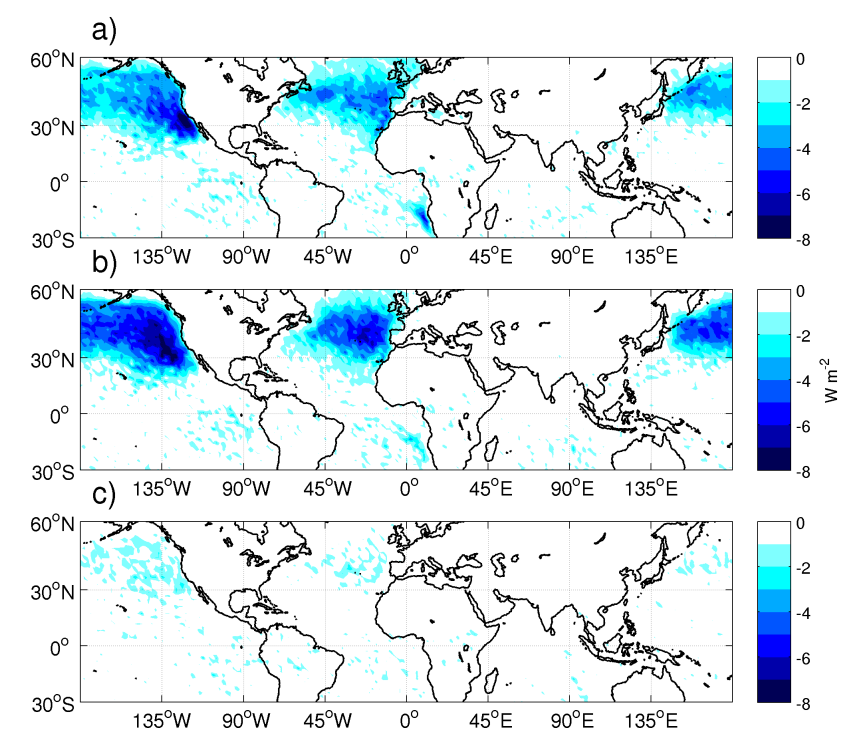

Fig. 4. 5 yr mean of effective radiative forcing compared to no-ships in simulations (a) ships-2010, (b) geo-wide and (c) ships-2020.

\subsection{Uncertainties and sensitivity tests}

\subsubsection{Uncertainty in modelling $\mathbf{P M}_{2.5}$ mass concentrations}

To evaluate the model's ability to simulate $\mathrm{PM}_{2.5}$ mass concentrations, we compared five-year-mean values of $\mathrm{PM}_{2.5}$ concentration from the simulation ships-2010 to observed annual mean values from remote measurement stations of the European Monitoring and Evaluation Programme (EMEP, 2013) and United States Interagency Monitoring of Protected Visual Environment (IMPROVE, 2013) networks. We used the last five available years for both data sets. Thus, EMEP data from 2006 to 2010 and IMPROVE data for the years 2007-2011 have been compared to the model values. In cases where more than one station corresponded to a single model grid box, we averaged the stations' data.

Figure 5 shows that the model tended to underestimate the $\mathrm{PM}_{2.5}$ concentrations both in US and Europe. The normalized mean biases were -0.74 and -0.34 for the EMEP and IMPROVE data, respectively. However, a more detailed analysis showed that there was a better agreement between the model and the observations in coastal areas and the differences were largest at inland stations. The global model grid size is of the order of $10000 \mathrm{~km}^{2}$, so it is difficult to compare a model value to a point-measurement value as the model cannot capture the subgrid-scale variability in aerosol concentrations especially near the emissions sources. It should be noted that in our scenarios, the ship-induced $\mathrm{PM}_{2.5}$ concentrations over the continents depend largely on aerosol transport over just one or two grid cells. This means that the simulated $\mathrm{PM}_{2.5}$ concentrations are sensitive to the accuracy of the advection scheme.
We analyzed the sensitivity of the excess mortality to the bias in the modelled $\mathrm{PM}_{2.5}$ using two different methods. In the first method, we assumed that the model underestimates $\mathrm{PM}_{2.5}$ concentrations in all simulations so that the ratio of the real (or corrected) and modeled $\mathrm{PM}_{2.5}$ concentrations equal the slope of the linear fit between measured and modeled $\mathrm{PM}_{2.5}$ concentrations (Fig. 5, red lines). Using this assumed dependency, we re-calculated the premature mortality due to shipping emissions with total $\mathrm{PM}_{2.5}$ concentrations multiplied with 1.61 (fit to EMEP data) or 1.18 (fit to IMPROVE data). Based on these calculations, the underestimation of $\mathrm{PM}_{2.5}$ concentrations lead to a relative error of between $-4 \%$ and $-6 \%$ for global total mortality in different scenarios. In the second method, we assumed that the model underestimates $\mathrm{PM}_{2.5}$ concentrations only in the simulation no-ships, and that the contribution from shipping emissions to $\mathrm{PM}_{2.5}$ is correct in the other simulations. The $\mathrm{PM}_{2.5}$ for the simulation no-ships was scaled following the same procedure as outlined above for the first method. For the other simulations we added the $\mathrm{PM}_{2.5}$ contribution from shipping in each simulation to the re-calculated $\mathrm{PM}_{2.5}$ of no-ships. With these re-calculated $\mathrm{PM}_{2.5}$ values we calculated the excess mortality in each scenario. The estimates for the relative errors in the mortality rate varied in different simulations from an overestimation of 50-54\% (fit to EMEP data) and of $15-16 \%$ (fit to IMPROVE data).

Based on these calculations, the uncertainty in the mortality estimates due to uncertainty in the $\mathrm{PM}_{2.5}$ concentrations can be significant. However, both methods probably overestimate the error as the modelled $\mathrm{PM}_{2.5}$ concentration compared better with measurements near the coasts where shipping emissions had the largest effect. Furthermore, the relative difference in excess mortality between different scenarios is not sensitive to a systematic bias in the model estimate for $\mathrm{PM}_{2.5}$. Thus, we expect that the main conclusions of this study are not significantly affected by the bias in the simulated $\mathrm{PM}_{2.5}$ concentrations.

\subsubsection{Sensitivity to strength of the subgrid-scale sulfate formation}

Changing the fraction of sulfur emissions emitted as primary sulfate particles in the model from $2.5 \%$ to $4.5 \%$ in ships-2010_45 and in geo-wide_45 intensified the impacts on both radiative balance and mortality rates (Table 2). In ships-2010_45, the global mean ERF was $-0.50 \mathrm{~W} \mathrm{~m}^{-2}$ $\left(-0.39 \mathrm{~W} \mathrm{~m}^{-2}\right.$ in ships-2010) and the total excess mortality due to shipping was 54300 (50200 in ships-2010) (Table 2). Despite these differences caused by varying the $\mathrm{SO}_{4}$ fraction, the difference in ERF between the simulations with standard emissions and the geoengineering runs (i.e. geo-wide minus ships-2010, and geo-wide_45 minus ships-2010_45) was the same $\left(-0.04 \mathrm{~W} \mathrm{~m}^{-2}\right)$ with both $\mathrm{SO}_{4}$ fractions (Table 2). This implies that the conclusions of this study do not depend on the chosen $\mathrm{SO}_{4}$ fraction. 

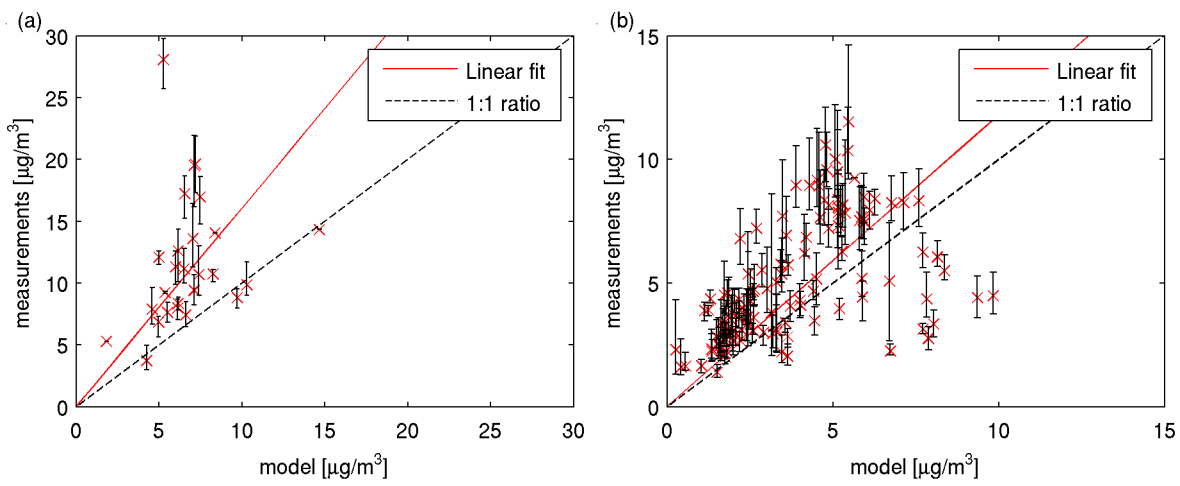

Fig. 5. Scatter plot of the observed annual mean $\mathrm{PM}_{2.5}$ concentrations at various sites and the simulated five-year mean surface $\mathrm{PM}_{2.5}$ in model grid boxes corresponding to these sites. The measurement data have been taken from (a) EMEP and (b) IMPROVE. The error bars represent the year-to-year variation and the red dots the five-year mean value of the observations. The dashed lines indicate the $1: 1$ ratio between the simulated values and observations, and the red lines indicate a linear fit to the data.

\subsubsection{Sensitivity to shipping emission data}

The total global shipping emissions are almost equal in the ACCMIP data set and in the combined data set from Wang et al. (2008) and Corbett et al. (2010) (Table 1). Yet, there are large spatial differences between the data sets. Most notably, the emissions in the simulation ships-2010_corbett are slightly more concentrated on the coasts than in the simulation ships-2010. In ships-2010, $48 \%$ of the shipping emissions are within the two-grid-cell emission reduction zone near the coasts and $31 \%$ in the one-grid-cell emission reduction zone. The respective fractions for ships-2010_corbett are $54 \%$ and $35 \%$. An exception to this pattern is that ships2010_corbett has lower emissions near the densely populated European coasts.

In general, the choice of the emission data set had little effect on our results (Table 2). The global total of premature mortality due to shipping was $6 \%$ lower in ships-2010_corbett than in ships-2010 (Table 2) and $19 \%$ higher in geo-wide_corbett than in geo-wide. The ERF was $0.02 \mathrm{~W} \mathrm{~m}^{-2}$ less negative in ships-2010_corbett than in ships-2010 and $0.03 \mathrm{~W} \mathrm{~m}^{-2}$ less negative in geowide_corbett than in geo-wide. The mortality difference between ships-2010 and geo-wide is larger than the difference between ships-2010_corbett and geo-wide_corbett. This is probably caused by the fact that shipping emissions near Europe are higher in the ACCMIP data set and emission reductions in the coastal zones have consequently stronger effect. Overall, however, the choice of emission data does not affect our conclusions.

\section{Discussion}

\subsection{Weighting the different emission scenarios}

The previous sections addressed how different scenarios of aerosol emissions from shipping would affect the global ra- diative balance and the number of premature deaths caused by shipping-induced particulate matter air pollution. To draw conclusions on the relative benefits of the different emission scenarios, we simplified the effects in two metrics: global mean ERF and global total premature mortality due to shipping emissions. We acknowledge that the former is an inadequate metric to fully express the climatic impacts of shipping emissions (Lauer et al., 2009), but these two metrics offer a tool to rate different scenarios with respect to climate and health effects. Figure 6 depicts both of these metrics for all our simulations using the simulation no-ships as a reference. Assuming that a large negative ERF is desirable, the optimal scenario would lie in the lower-left corner where shipping emissions have no adverse health effects but a large cooling effect. Optimal level of ERF is of course a subjective definition, because some regions might benefit from stronger cooling and others from less cooling (MacMartin et al., 2012). Note that, because ERF and total premature mortality rate are not comparable, the distance from the lower-left corner cannot be used as measure of optimality. For example, the geoengineering simulations are near the "optimal" corner, but have clearly larger mortality rates than ships-2020, which would be the most favorable in terms of health benefits, but offer little cooling compared to the other scenarios.

Most importantly, we find that the cooling effect and the total mortality rate combination of the simulation ships-2010 is not Pareto optimal (i.e. there are potential scenarios in which the mortality rate can be reduced without a reduction in the climate-cooling effect). Both geoengineering simulations geo-wide and geo-narrow have at least the same cooling effect but lower mortality rates than ships-2010. One cannot put simulations geo-wide, geo-narrow, and ships-2020 into a preferred order without deciding some conversion method between ERF and mortality rate. For example, geo-narrow offered a stronger cooling $\left(-0.53 \mathrm{~W} \mathrm{~m}^{-2}\right.$ vs. $\left.-0.43 \mathrm{~W} \mathrm{~m}^{-2}\right)$ than geo-wide but also had a greater annual mortality rate $\left(34900 \mathrm{yr}^{-1}\right.$ vs. $15400 \mathrm{yr}^{-1}$ ). 


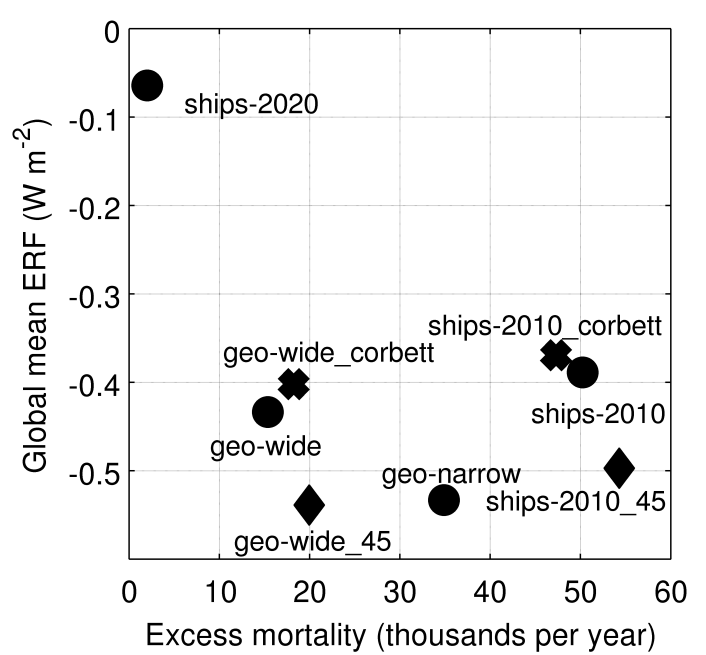

Fig. 6. Global premature mortality due to shipping ( $x$ axis) and global mean effective radiative forcing ( $y$ axis) with respect to noships for different simulations. The upper-left corner represents a zero effect of shipping emissions and the lower-left corner the "optimal" combination of mortality avoided and radiative effects where shipping emissions do not cause premature deaths, but have a large cooling effect. Circles represent the main simulations where ACCMIP shipping emissions were used as a baseline. Simulations marked with diamonds (ships-2010_45 and geo-wide_45) were run with $4.5 \%$ (instead of $2.5 \%$ ) of sulfur mass emissions from ships emitted as primary sulfate. The crosses denote simulations in which shipping emissions inventories compiled by Wang et al. (2008) and Corbett et al. (2010) were used to construct the actual shipping emissions.

\subsection{Limitations of the study}

In our simulations, aerosols from shipping emissions caused a strongly localized radiative effect (Fig. 4b). Previous studies have shown that regional forcing over the oceans creates a global cooling effect, although the regions with strong local radiative forcing cool the most (Hill and Ming, 2012; Jones et al., 2009; Rasch et al., 2009). This would probably be true also for the cooling effect from shipping emissions. Still, precipitation response depends much more strongly on the location of the forcing and cannot be predicted by using global mean values (Shindell et al., 2012). Jones et al. (2009) found that modifying marine clouds could cause a dramatic decrease of precipitation over the Amazon rain forest. The local forcings in our study are smaller (especially if geoengineering simulations are compared against ships-2010) which would probably limit the extent of side effects. However, the possibility of such detrimental sideeffects cannot be entirely excluded. It cannot even be ruled out, that removing aerosol forcing from shipping could cause detrimental precipitation changes in addition to the warming effect. Thus, further climate model studies with dynamic ocean model are needed to fully assess the climate effects of different shipping scenarios.

Our study has been restricted to the effects of sulfur and organic carbon emissions, which are the main emission components expected to change when the fuel sulfur content is manipulated (Lack et al., 2009). While it is important to remember that carbon dioxide emissions from shipping will in the long term dominate over the aerosol emissions when the total radiative impact of shipping emissions is assessed (Fuglestvedt et al., 2009), the change in the fuel sulfur content, which is the focus of this study, is unlikely to have a significant effect on the carbon dioxide emissions. This is because carbon dioxide emissions from shipping are mostly determined by the efficiency of ship motors or ship design (ICCT, 2007), not the fuel composition. Therefore, an increase of ship fuel sulfur content in certain regions would not directly change the total carbon dioxide emissions from shipping or hinder efforts to reduce these emissions by other means. One point to remember, however, is that if the aerosol cooling from shipping was to be maintained to slow down global warming, sulfur emissions from shipping would need to be continued on timescales comparable to lifetimes of long-lived greenhouse gases (i.e. centuries or millennia) due to the short lifetime of aerosol particles (Fuglestvedt et al., 2009; Brovkin et al., 2007).

The increased sulfur emissions over the open oceans in the geoengineering simulations could potentially increase ocean acidification. Hassellöv et al. (2013) concludes that ocean acidification due to $\mathrm{SO}_{\mathrm{x}}$ and $\mathrm{NO}_{\mathrm{x}}$ from shipping emissions could be in the same order of magnitude as the effect of increased $\mathrm{CO}_{2}$ concentration near the major shipping routes. However, the coastal areas, which are most vulnerable to acidification (Doney et al., 2007), had either present-day or decreased sulfur emissions in our simulations, although the coastal impact of acidifying compounds transported from the open oceans cannot be totally excluded based on our simulations.

\subsection{International law and manipulation of ship fuel sulfur content}

Increasing aerosol emissions deliberately to create a global cooling effect would raise complex and controversial legal issues (Redgwel, 2011). Such geoengineering could violate several existing international agreements and international customary rules. In addition, the fuel sulfur content that we have assumed in the geoengineering scenarios would exceed the sulfur limits imposed by the MARPOL Annex VI (IMO, 2008). So far, IMO has focused on the prevention of air pollution from ships. In addition, IMO has done extensive climaterelated work to further improve energy efficiency and reduce greenhouse gases from international shipping. In these circumstances, a proposal to increase sulfur content would be controversial and might be regarded as an attempt to undermine the ongoing work and the important achievements 
already made. With regard to other geoengineering techniques, similar radiative effects without the adverse health and environmental effects could possibly be achieved with sea spray injections (Latham, 1990). However, there are several risks and legal issues related also to sea spray injections.

\section{Conclusions}

We have simulated the effects of aerosol emissions from shipping on premature mortality and Earth's radiative balance with an aerosol-climate model ECHAM-HAMMOZ. We compared a present-day shipping emission scenario with two geoengineering scenarios with doubled sulfur dioxide emissions over the open oceans and reduced sulfur emissions near the continents, and a scenario corresponding roughly to emission regulation as currently considered for the year 2020 by the International Maritime Organization in MARPOL Annex VI (IMO, 2008).

According to our results, notable improvements in air quality are possible without losing the current cooling effect from ship-emitted aerosol. In the two geoengineering scenarios, the present-day radiative cooling was increased (by $10 \%$ and $36 \%$ ) with simultaneous significant reductions in premature mortality from aerosol emissions from shipping (reductions of $69 \%$ and $31 \%$ ). Furthermore, our model indicates that the shipping emission regulation planned for the year 2020 would substantially reduce both the cooling effect $(83 \%)$ and global premature mortality $(96 \%)$ caused by aerosol emissions from shipping, confirming the findings of previous studies (Lauer et al., 2009; Winebrake et al., 2009).

One important aspect of our results is that regulation of aerosol emissions from shipping near the continents is vital for reducing adverse health effects. Not implementing the ship fuel sulfur content regulation in coastal waters would cause tens of thousands premature deaths annually. Thus, our results should not be interpreted to support removing the regulation of shipping emissions in the existing emission control areas.

Although the emissions from coastal water dominate the health impacts of shipping emissions, emissions originating from the open oceans (several hundreds of kilometers from the coasts) can have significant adverse health effects over the continents due to long-range transport of the pollutants. This can been seen in the large difference in premature mortality (about 13000 deaths per year) between the geoengineering simulation (geo-wide) and the simulation corresponding to the year 2020 emission controls with equal emission reductions near the coasts.

The cooling effect of aerosol emissions from shipping could be preserved by manipulating aerosol emissions from shipping over the open oceans. However, such manipulation is not without risks, would be in conflict with current international agreements, and is always a trade-off between climate cooling and adverse health effects. Therefore, it should be considered only if radical measures to tackle climate change are needed.

Acknowledgements. We thank K. Peters for kindly providing us with the model modifications to improve the treatment of aerosol emissions from shipping and for giving detailed instruction how to implement them. We also thank T. Kühn for interpolating the ACCMIP emissions for ECHAM, and T. Ekholm and NASA for providing the gridded data set of the world's countries. We are grateful to W. J. Collins and two anonymous referees, whose comments and suggestions helped to improve the paper. The ECHAM-HAMMOZ model is developed by a consortium composed of ETH Zurich, Max Planck Institut für Meteorologie, Forschungszentrum Jülich, University of Oxford, and the Finnish Meteorological Institute and managed by the Center for Climate Systems Modeling (C2SM) at ETH Zurich. This work was funded by the Maj and Tor Nessling foundation (grant 2012116) and the Academy of Finland via the Research Program on Climate Change (FICCA) (project 140867) and an Academy Research Fellow position (decision 250348). A. Schmidt was funded by an Academic Research Fellowship from the School of Earth and Environment, University of Leeds.

Edited by: I. Riipinen

\section{References}

Abdul-Razzak, H. and Ghan, S. J.: A parameterization of aerosol activation: 2. multiple aerosol types, J. Geophys. Res., 105, 68376844, 2000.

Brovkin, V., Petoukhov, V., Claussen, M., Bauer, E., Archer, D., and Jaeger, C.: Geoengineering climate by stratospheric sulfur injections: Earth system vulnerability to technological failure, Climatic Change, 92, 243-259, doi:10.1007/s10584-008-9490$1,2009$.

Christensen, M. W. and Stephens, G. L.: Microphysical and macrophysical responses of marine stratocumulus polluted by underlying ships: evidence of cloud deepening, J. Geophys. Res., 116, D03201, doi:10.1029/2010JD014638, 2011.

Coakley, J. A., Bernstein, R. T. L., and Durkee, P. A.: Effect of shipstack effluents on cloud reflectivity, Science, 237, 1020-1022, 1987.

Cohen, A. J., Ross Anderson, H., Ostro, B., Pandey, K. D., Krzyzanowski, M., Kunzli, N., Gutschmidt, K., Pope, A., Romieu, I., Samet, J. M., and Smith, K.: The global burden of disease due to outdoor air pollution, J. Toxicol. Environ. Health A, 68, 1301-1307, 2005.

Corbett, J. J., Winebrake, J. J., Green, E. H., Kasibhatla, P., Eyring, V., and Lauer, A.: Mortality from ship emissions: a global assessment, Environ. Sci. Technol., 41, 8512-8518, 2007.

Corbett, J. J., Lack, D. A., Winebrake, J. J., Harder, S., Silberman, J. A., and Gold, M.: Arctic shipping emissions inventories and future scenarios, Atmos. Chem. Phys., 10, 9689-9704, doi:10.5194/acp-10-9689-2010, 2010.

Crutzen, P.: Albedo enhancement by stratospheric sulfur injections: a contribution to resolve a policy dilemma?, Clim. Change, 77 211-220, 2006.

Dee, D. P., Uppala, S. M., Simmons, A. J., Berrisford, P., Poli, P., Kobayashi, S., Andrae, U., Balmaseda, M. A., Balsamo, G., 
Bauer, P., Bechtold, P., Beljaars, A. C. M., van de Berg, L., Bidlot, J., Bormann, N., Delsol, C., Dragani, R., Fuentes, M., Geer, A. J., Haimberger, L., Healy, S. B., Hersbach, H., Hólm, E. V., Isaksen, L., Kållberg, P., Köhler, M., Matricardi, M., McNally, A. P., Monge-Sanz, B. M., Morcrette, J.-J., Park, B.-K., Peubey, C., de Rosnay, P., Tavolato, C., Thépaut, J.-N., and Vitart, F.: The ERA-Interim reanalysis: configuration and performance of the data assimilation system, Q. J. Roy. Meteor. Soc., 137, 553-597, 2011.

Dentener, F., Kinne, S., Bond, T., Boucher, O., Cofala, J., Generoso, S., Ginoux, P., Gong, S., Hoelzemann, J. J., Ito, A., Marelli, L., Penner, J. E., Putaud, J.-P., Textor, C., Schulz, M., van der Werf, G. R., and Wilson, J.: Emissions of primary aerosol and precursor gases in the years 2000 and 1750 prescribed data-sets for AeroCom, Atmos. Chem. Phys., 6, 4321-4344, doi:10.5194/acp-64321-2006, 2006.

Doney, S. C., Mahowald, N., Lima, I., Feely, R. A., Mackenzie, F. T., Lamarque, J., and Rasch, P. J.: Impact of anthropogenic atmospheric nitrogen and sulfur deposition on ocean acidification and the inorganic carbon system, P. Natl. Acad. Sci. USA, 104, 14580-14585, 2007.

EMEP (European Monitoring and Evaluation Programme): available at: http://www.emep.int/, last access: 24 January 2013, 2013.

Eyring, V., Isaksen, I. S. A., Berntsen, T., Collins, W. J., Corbett, J. J., Endresen, O., Grainger, R. G., Moldanova, J., Schlager, H., and Stevenson, D. S.: Transport impacts on atmosphere and climate: shipping, Atmos. Environ., 44, 4735-4771, 2010.

Fox, T. A. and Chapman, L.: Engineering geo-engineering, Meteorol. Appl., 18, 1-8, 2011.

Fuglestvedt, J., Berntsen, T., Eyring, V., Isaksen, I., Lee, D. S., and Sausen, R.: Shipping emissions: from cooling to warming of climate and reducing impacts on health, Environ. Sci. Technol., 43, 9057-9062, 2009.

Hassellöv, I.-M., Turner, D., Lauer, A., and Corbett, J. J.: Shipping contributes to ocean acidification, Geophys. Res. Lett., 40, 27312736, doi:10.1002/grl.50521, 2013.

Haywood, J., Donner, L., Jones, A., and Golaz, J.-C.: Global indirect radiative forcing caused by aerosols: IPCC (2007) and beyond, in: Clouds in the Perturbed Climate System: Their Relationship to Energy Balance, Atmospheric Dynamics, and Precipitation, edited by: Heintzenberg, J. and Charlson, R. J., Strüngmann Forum Report, MIT Press, Cambridge, USA, 451-467, 2009.

Hill, S. and Ming, Y.: Nonlinear climate response to regional brightening of tropical marine stratocumulus, Geophys. Res. Lett., 39, L15707, doi:10.1029/2012GL052064, 2012.

ICCT (The International Council on Clean Transportation): Air pollution and Greenhouse Gas Emissions from Ocean-going Ships: Impacts, Mitigation Options and Opportunities for Managing Growth, The International Council on Clean Transportation, 2007.

IMO: International Convention for the Prevention of Pollution from Ships, London, 2 November 1973 and the Protocol, London, relating thereto (MARPOL 73/78), available at: http://www.imo. org/last access: 17 February 1978, 1978.

IMO: Amendments to the Annex of the Protocol of 1997 to amend the International Convention for the Prevention of Pollution from Ships, 1973, as modified by the Protocol of 1978 relating thereto
(Revised MARPOL Annex VI), IMO MEPC.176(58), available at: http://www.imo.org/ (last access: March 2013), 2008.

IMO: Amendments to the Annex of the Protocol of 1997 to amend the International Convention for the Prevention of Pollution from Ships, 1973, as modified by the Protocol of 1978 relating thereto (North American Emission Control Area), IMO MEPC.190(60), available at: http://www.imo.org/ (last access: March 2013), 2010.

IMPROVE (United States Interagency Monitoring of Protected Visual Environment), available at: http://vista.cira.colostate.edu/ improve/last access: 29 January 2013, 2013.

Jones, A., Haywood, J., and Boucher, O.: Climate impacts of geoengineering marine stratocumulus clouds, J. Geophys. Res., 114, D10106, doi:10.1029/2008JD011450, 2009.

Jonsson, ̊. M., Westerlund, J., and Hallquist, M.: Size-resolved particle emission factors for individual ships, Geophys. Res. Lett., 38, L13809, doi:10.1029/2011GL047672, 2011.

Kazil, J. and Lovejoy, E. R.: A semi-analytical method for calculating rates of new sulfate aerosol formation from the gas phase, Atmos. Chem. Phys., 7, 3447-3459, doi:10.5194/acp-7-3447-2007, 2007.

Koch, D. and Del Genio, A. D.: Black carbon semi-direct effects on cloud cover: review and synthesis, Atmos. Chem. Phys., 10, 7685-7696, doi:10.5194/acp-10-7685-2010, 2010.

Lack, D. A. and Corbett, J. J.: Black carbon from ships: a review of the effects of ship speed, fuel quality and exhaust gas scrubbing, Atmos. Chem. Phys., 12, 3985-4000, doi:10.5194/acp-12-39852012, 2012.

Lack, D. A., Corbett, J. J., Onasch, T., Lerner, B., Massoli, P., Quinn, P. K., Bates, T. S., Covert, D. S., Coffman, D., Sierau, B., Herndon, S., Allan, J., Baynard, T., Lovejoy, E., Ravishankara, A. R., and Williams, E.: Particulate emissions from commercial shipping: chemical, physical, and optical properties, J. Geophys. Res., 114, D00F04, doi:10.1029/2008JD011300, 2009.

Latham, J.: Control of global warming?, Nature, 347, 339-340, 1990.

Lauer, A., Eyring, V., Corbett, J. J., Wang, C., and Winebrake, J. $\mathrm{J} .:$ Assessment of near-future policy instruments for oceangoing shipping: impact on atmospheric aerosol burdens and the Earth's radiation budget, Environ. Sci. Technol., 43, 5592-5598, 2009.

Lerner, J., Matthews, E., and Fung, I.: Methane emission from animals: a global high-resolution database, Global Biogeochem. Cy., 2, 139-156, 1988.

Lieke, K. I., Rosenørn, T., Pedersen, J., Larsson, D., Kling J., Fuglsang, K., Bilde, M.: Micro- and Nanostructural Characteristics of Particles Before and After an Exhaust Gas Recirculation System Scrubber, Aerosol Sci. Tech., 47, 1038-1046, 2013.

Lin, H. and Leaitch, W.: Development of an in-cloud aerosol activation parameterization for climate modelling, in: Proceedings of the WMO Workshop on Measurement of Cloud Properties for Forecasts of Weather, Air Quality and Climate, Mexico City, Publisher is World Meteorological Organization (WMO), 328335, 1997.

Lohmann, U. and Feichter, J.: Global indirect aerosol effects: a review, Atmos. Chem. Phys., 5, 715-737, doi:10.5194/acp-5-7152005, 2005.

Lohmann, U. and Hoose, C.: Sensitivity studies of different aerosol indirect effects in mixed-phase clouds, Atmos. Chem. Phys., 9, 8917-8934, doi:10.5194/acp-9-8917-2009, 2009. 
Lohmann, U., Rotstayn, L., Storelvmo, T., Jones, A., Menon, S., Quaas, J., Ekman, A. M. L., Koch, D., and Ruedy, R.: Total aerosol effect: radiative forcing or radiative flux perturbation?, Atmos. Chem. Phys., 10, 3235-3246, doi:10.5194/acp-10-32352010, 2010.

Löndahl, J., Swietlicki, E., Lindgren, E., and Loft, S.: Aerosol exposure versus aerosol cooling of climate: what is the optimal emission reduction strategy for human health?, Atmos. Chem. Phys., 10, 9441-9449, doi:10.5194/acp-10-9441-2010, 2010.

Luo, G. and Yu, F.: Sensitivity of global cloud condensation nuclei concentrations to primary sulfate emission parameterizations, Atmos. Chem. Phys., 11, 1949-1959, doi:10.5194/acp-111949-2011, 2011.

MacMartin, D. G., Keith, D. W., Kravitz, B., and Caldeira, K.: Management of trade-offs in geoengineering through optimal choice of non-uniform radiative forcing, Nat. Clim. Change, 3, 365-368, doi:10.1038/nclimate1722, 2012.

Myhre, G., Samset, B. H., Schulz, M., Balkanski, Y., Bauer, S., Berntsen, T. K., Bian, H., Bellouin, N., Chin, M., Diehl, T., Easter, R. C., Feichter, J., Ghan, S. J., Hauglustaine, D., Iversen, T., Kinne, S., Kirkevåg, A., Lamarque, J.-F., Lin, G., Liu, X., Lund, M. T., Luo, G., Ma, X., van Noije, T., Penner, J. E., Rasch, P. J., Ruiz, A., Seland, Ø., Skeie, R. B., Stier, P., Takemura, T., Tsigaridis, K., Wang, P., Wang, Z., Xu, L., Yu, H., Yu, F., Yoon, J.-H., Zhang, K., Zhang, H., and Zhou, C.: Radiative forcing of the direct aerosol effect from AeroCom Phase II simulations, Atmos. Chem. Phys., 13, 1853-1877, doi:10.5194/acp-13-18532013, 2013

Ostro, B.: Outdoor air pollution: assessing the environmental burden of disease at national and local levels, WHO Environmental Burden of Disease Series, 5, Geneva, World Health Organization, 2004.

Partanen, A.-I., Kokkola, H., Romakkaniemi, S., Kerminen, V.-M., Lehtinen, K. E. J., Bergman, T., Arola, A., and Korhonen, H.: Direct and indirect effects of sea spray geoengineering and the role of injected particle size, J. Geophys. Res., 117, D02203, doi:10.1029/2011JD016428, 2012.

Peters, K., Stier, P., Quaas, J., and Graß1, H.: Aerosol indirect effects from shipping emissions: sensitivity studies with the global aerosol-climate model ECHAM-HAM, Atmos. Chem. Phys., 12, 5985-6007, doi:10.5194/acp-12-5985-2012, 2012.

Peters, K., Stier, P., Quaas, J., and Graß1, H.: Corrigendum to "Aerosol indirect effects from shipping emissions: sensitivity studies with the global aerosol-climate model ECHAM-HAM" published in Atmos. Chem. Phys., 12, 5985-6007, 2012, Atmos. Chem. Phys., 13, 6429-6430, doi:10.5194/acp-13-64292013, 2013.

Petzold, A., Hasselbach, J., Lauer, P., Baumann, R., Franke, K., Gurk, C., Schlager, H., and Weingartner, E.: Experimental studies on particle emissions from cruising ship, their characteristic properties, transformation and atmospheric lifetime in the marine boundary layer, Atmos. Chem. Phys., 8, 2387-2403, doi:10.5194/acp-8-2387-2008, 2008.

Pope III, C. A. and Dockery, D. W.: Health effects of fine particulate air pollution: lines that connect, J. Air Waste Manag. Assoc., 56, 709-742, 2006.

Rasch, P. J., Latham, J., and Chen, C.-C.: Geoengineering by cloud seeding: influence on sea ice and climate system, Environ. Res. Lett., 4, 045112, doi:10.1088/1748-9326/4/4/045112, 2009.
Redgwel,C.: Geoengineering the climate: techological solutions to mitigation - failure or continuing carbon addicction?, Carb. Clim. Law Rev., 2, 178-189, 2011.

Riahi, K., Grübler, A., and Nakicenovic, N.: Scenarios of long-term socio-economic and environmental development under climate stabilization, Technol. Forecast. Soc., 74, 887-935, 2007.

Riahi, K., Rao, S., Krey, V., Cho, C., Chirkov, V., Fischer, G., Kindermann, G., Nakicenovic, N., and Rafaj, P.: RCP 8.5 - a scenario of comparatively high greenhouse gas emissions, Clim. Change, 109, 33-57, 2011.

Robock, A.: 20 reasons why geoengineering may be a bad idea, Bull. Atomic Scientists, 64, 14-18, 2008.

SEDAC (NASA Socioeconomic Data and Applications Center): Gridded Population of the World, Version 3 (GPWv3): Population Count Grid, Future Estimates, Center for International Earth Science Information Network (CIESIN)/Columbia University, United Nations Food and Agriculture Programme (FAO), and Centro Internacional de Agricultura Tropical (CIAT), available at: http://sedac.ciesin.columbia.edu/data/ set/gpw-v3-population-count-future-estimates, last access: 16 November 2012, 2005.

Shindell, D. T., Voulgarakis, A., Faluvegi, G., and Milly, G.: Precipitation response to regional radiative forcing, Atmos. Chem. Phys., 12, 6969-6982, doi:10.5194/acp-12-6969-2012, 2012.

Stevens, R. G., Pierce, J. R., Brock, C. A., Reed, M. K., Crawford, J. H., Holloway, J. S., Ryerson, T. B., Huey, L. G., and Nowak, J. B.: Nucleation and growth of sulfate aerosol in coal-fired power plant plumes: sensitivity to background aerosol and meteorology, Atmos. Chem. Phys., 12, 189-206, doi:10.5194/acp12-189-2012, 2012.

Stier, P., Feichter, J., Kinne, S., Kloster, S., Vignati, E., Wilson, J., Ganzeveld, L., Tegen, I., Werner, M., Balkanski, Y., Schulz, M., Boucher, O., Minikin, A., and Petzold, A.: The aerosol-climate model ECHAM5-HAM, Atmos. Chem. Phys., 5, 1125-1156, doi:10.5194/acp-5-1125-2005, 2005.

Vignati, E., Wilson, J., and Stier, P.: M7: an efficient sizeresolved aerosol microphysics module for large-scale aerosol transport models, J. Geophys. Res., 109, D22202, doi:10.1029/2003JD004485, 2004

Wang, C., Corbett, J. J., and Firestone, J.: Improving spatial representation of global ship emissions inventories, Environ. Sci. Technol., 42, 193-199, 2008.

Winebrake, J. J., Corbett, J. J., Green, E. H., Lauer, A., and Eyring, V.: Mitigating the health impacts of pollution from oceangoing shipping: an assessment of low-sulfur fuel mandates, Environ. Sci. Technol., 43, 4776-4782, 2009.

WHO (World Health Organization): The global burden of disease: 2004 update, Geneva, 2008.

WHO (World Health Organization): Regional offices, available at: http://www.who.int/about/regions/en/index.html, last access: December 2012, 2012.

Zhang, K., O’Donnell, D., Kazil, J., Stier, P., Kinne, S., Lohmann, U., Ferrachat, S., Croft, B., Quaas, J., Wan, H., Rast, S., and Feichter, J.: The global aerosol-climate model ECHAM-HAM, version 2: sensitivity to improvements in process representations, Atmos. Chem. Phys., 12, 8911-8949, doi:10.5194/acp-12-89112012, 2012. 